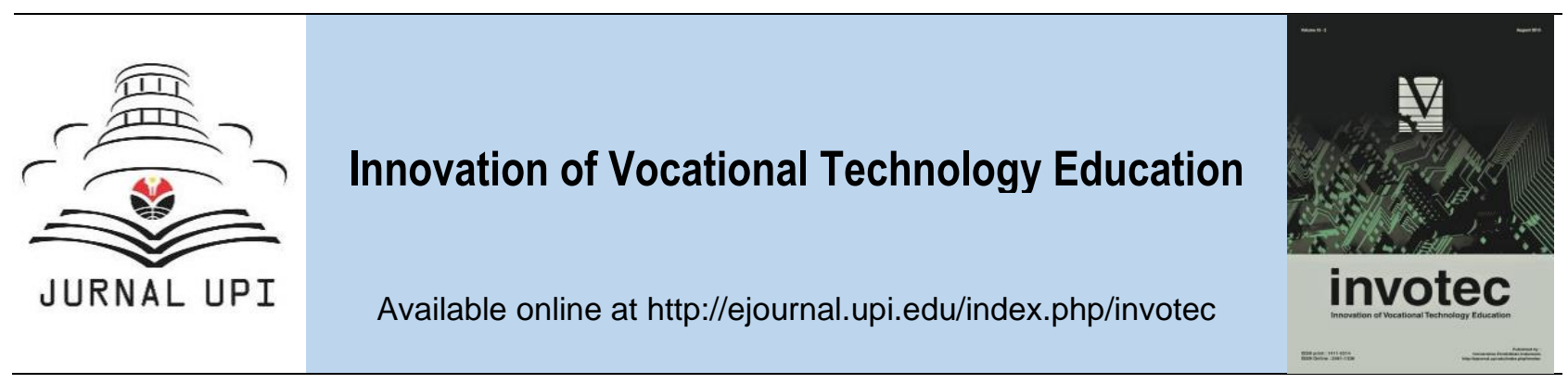

\title{
The Instrumental Framework to Measuring Environmental Awareness
}

\author{
R. A. Vesitara Kencanasari, Usep Surahman, and Asep Yudi Permana \\ Universitas Pendidikan Indonesia, Bandung, Indonesia
}

\section{ARTICLE INFO}

Article history:

Received: 26 June 2019

Received in revised form: 09 July 2019

Accepted: 25 August 2019

Available online: 31 August 2019

Keywords:

instrument;

measuring;

enviromental awereness

Authors email:

ra.vesitara@upi.edu

usepsurahman@upi.edu

yudi.permana@upi.edu

\section{A B S T R A C T}

Environmental awareness needs to be increased because it plays an important role for the survival of life. To find out the level of public awareness of the environment it is necessary to conduct a workshop or environmental awareness training. The purpose of this study is to identify and generate an instrument indicator to measure the environmental awareness. This article looks at a variety of relevant literature in order to explore the aspects that must be present In the instrument to measuring the environmental awareness level. The literature study results are obtained the aspects that must have to consist of two aspects namely pro-environment and not pro-environment, in which indicators are made from the start of knowledge, attitudes and behavior. The implication of this literature review is to provide information and recommend a set of a framework to academics in making instruments measuring the level of public awareness of the environment.

\section{Introduction}

The growth of the population of people in the world is increasing rapidly. The rapid population growth causes the land need for a shelter increasingly large. Extensive land clearing for housing needs is one factor that can cause environmental damage (Belinda, 2017). Efforts in conveying information about the importance of the community environmental awareness can be done through workshops or training for the community around the company. CSR funds from companies can be allocated for environmental awareness workshops. This is done because everyone is required to protect and preserve the environment from various pollutants. The International Organization for Standardization (ISO) issues a series of ISO 14000 standards consisting of various aspects of environmental management (Haslinda \& Fuong, 2010).

Everyone must maintain a healthy and good environment. The environment will have a good influence if treated and maintained well, otherwise it will have a bad influence to humans. Over the past few years, many ways have been made to shape environmental awareness (Ham, Mrčela, \& Horvat, 2016). Environmental awareness is an important responsibility of every individual. 
Consciousness is knowing one's behavior, which is a conscious mind that regulates reason and can make the choices about what is desired, for example, good, bad, beautiful, etc (Chen, Huang, \& Lin, 2019). Environmental awareness is an effort to increase awareness so that they do not only know about waste, pollution, greening, and protection of endangered animals, but rather to raise awareness of the human environment, so that they love the motherland to build a just, prosperous and sustainable Indonesian (Salim, 1982).

The environment is a state around our dwelling consisting of nature, humans, animals and other inanimate objects. The environment is the main thing of life in the world, without the environment we cannot interact and socialize with others. Thus, the environment is all that exists outside an organization, which consists of: (1) Abiotic (Dead Environment), namely the environment outside an organism consists of objects or natural factors that are not alive. (2) Biotics (Environment), namely the environment outside an organization, which consists of living organisms, such as plants, animals and humans (Husna et al., 2014).

Environmental awareness is built on the basis of knowledge, attitudes and behaviors which are applied through the actions. Knowledge of environmental awareness is preceded by knowing about waste, pollution, greening, and endangered animals protection to increase the environmental awareness (Salim, 1982). Environmental awareness can be interpreted as an attitude regarding the consequences of behavior in the human environment. The environmental care attitude is a reaction to environmental problems in a certain way (Culiberg \& Rojšek, 2008). After knowledge, attitude, and good behavior in treating the environment, the things that human have to do are trying to not damage the environment.

Environmental awareness must be implemented by conducting socialization about the importance of protecting the environment. The socialization process can be carried out by holding seminars, workshops and training to raising public awareness in protecting the environment (Ham, Mrčela, \& Horvat, 2016). To see an increase in community awareness in attending workshops or environmental training, an instrument to measure the success of the training or workshop needs to be made. This research focus is to review the literature of research findings related to the measurement of environmental awareness. This is important, become a guide when making instruments for measuring environmental awareness at workshops or environmental awareness training.

The purpose of this study is to identify and generate an instrument indicator to measure the environmental awareness.

\section{Method}

This literature study conducted a search of more than 105 journals, with detailed articles covering major topics of environmental awareness and measuring environmental awareness that were processed and compiled to be combined. The literature search waged by accessing Scopus, 
Science Direct, Sage Journals and Springer. Articles were taken in July-August by limiting articles published in 2010 to 2019. Articles are searched using the keywords "environmental awareness", "measuring environmental awareness", and "environmental awareness training", which are used to simplify the process of searching literature. Table 1 presents the frequency for sorting journals.

Table 1. Frequency of journal paper search

\begin{tabular}{lll}
\hline No & Keyword & Frequency \\
\hline 1 & Environmental awareness & 53 \\
2 & Measuring environmental awareness & 21 \\
3 & Environmental awareness training & 30 \\
& Total & 105 \\
\hline
\end{tabular}

The articles are analyzed thoroughly and in part to ease the grouping and sorting. Furthermore irrelevant articles are separated according to needs. From this process produced 24 relevant and taken articles that focus on studying measuring environmental awareness .

The arcticles are then analyzed to see the focus of research, the scope of the problem under study, and the research results. The findings are conceptualized into a literature review that has a novelty value (Hsieh \& Shannon, 2005). Then the articles are explored and combined in the form of a journal review (Douglas et al., 2008 ). In the chapter discussion is criticized by giving ideas to answer the objectives of literature so as to add insight to the reader. These results can be used as a reference for academics to identify aspects of measuring environmental awareness. A relevant article were analyzed and summarized as shown in the example of Table 2.

Table 2. Example summary of journal review

\begin{tabular}{|c|c|c|c|c|}
\hline Study & Participant & Context & Type of Data & Basic Finding \\
\hline $\begin{array}{l}\text { Ham, Mrcela, } \\
\text { and Horvat } \\
\text { (2016) } \\
\text { "Insight for } \\
\text { Measuring } \\
\text { Environmenta } \\
\text { I Awareness" }\end{array}$ & $\begin{array}{l}27 \quad \text { Member } \\
\text { States of } \\
\text { European } \\
\text { Union }\end{array}$ & $\begin{array}{l}\text { The survey } \\
\text { showed the } \\
\text { willingness } \\
\text { transformation } \\
\text { into actual pro } \\
\text { environmental } \\
\text { behavior as a } \\
\text { main } \\
\text { challenges of } \\
\text { green } \\
\text { marketing }\end{array}$ & $\begin{array}{l}\text { Survey } \\
\text { Questionnaire }\end{array}$ & $\begin{array}{l}\text { The result of this research } \\
\text { showed that most of } \\
\text { participants have the } \\
\text { willingness to buy } \\
\text { environmental friendly } \\
\text { products even if they are } \\
\text { slightly more expensive. } \\
\text { Relationship between } \\
\text { willingness to buy } \\
\text { environmentally friendly } \\
\text { products and actual } \\
\text { actions are related. } \\
\text { People have to conclude } \\
\text { before making decisions } \\
\text { on introducing measures to } \\
\text { encourage certain } \\
\text { environmental behavior } \\
\text { form. }\end{array}$ \\
\hline
\end{tabular}


Journals obtained were selected based on abstracts, participants, published years, research findings and conclusions. There are 24 journals which have the potential to be studied as described in Table 3.

Table 3. Journals reviewed in this study

\begin{tabular}{|c|c|}
\hline Title & \\
\hline nprove financial performance? A meta-analytical & \\
\hline $\begin{array}{l}\text { Developing Environmental Awareness Through Open and Distance Learning System } \\
\text { (Anbalagan \& Srivastava, 2016). }\end{array}$ & 20 \\
\hline age: Effects on problem awareness and behav & 20 \\
\hline $\begin{array}{l}\text { ' learning for environmental sustainability: Testin } \\
\text { tourism experiences using structural equation } \\
011 \text { ). }\end{array}$ & 201 \\
\hline of environmental awareness an & 2019 \\
\hline Enhancing & 2010 \\
\hline $\begin{array}{l}\text { Consumers' responses to CSR activities: The Linkage Between } \\
\text { Purchase Intention (Lee \& Shin, 2010). }\end{array}$ & 2010 \\
\hline Responsibility and Shareholder Reactio & 2013 \\
\hline $\begin{array}{l}\text { Insights for Measuring Environmental Awareness. Ekonomski Vjesnik (Ham, Mrčela, \& } \\
\text { Horvat, 2016). }\end{array}$ & 2016 \\
\hline $\begin{array}{l}\text { Consumer Attitude and Purchase Intention Toward Green Energy Brands (Hartn } \\
\text { Apaolaza-Ibáñez, 2012). }\end{array}$ & \\
\hline tal Awareness in Daily Activities Measured by Nega & 20 \\
\hline g global & 20 \\
\hline Her & 201 \\
\hline leasuring Environmental Consci & 201 \\
\hline & 2016 \\
\hline
\end{tabular}

Age and Environmental Sustainability: A Meta-Analysis (M. Wiernik, S. Ones, \& Dilchert, 2013 2013)

Designing training for teaching environmental toxicology to specialized pharmacists (Peña- 2015 Fernández, González-Muñoz, \& de los Ángeles Peña, 2015).

Measuring Love and Care for Nature (Perkins, 2010).

The Comprehensiveness of Environmental Management Systems: The Influence of 2015 Institutional Pressures and The Impact on Environmental Performance (Phan \& Baird, 2015).

Minimization of Air Pollution Through Sustainable Development of Eco-Industrial Parks in China Effects of Managers' Environmental Awareness on The Relationship Between

Practice and Performance (Sudarman et al., 2019).

Green Consumer: Description of the Joglosemar Community's Level of Awareness and 2012 Concern for Environmental Sustainability (Waskito \& Harsono, 2012).

Heritage Tourism, CSR and The Role Employee Environmental Behavior (Wells et al., 2015 2015).

The impact of electronic environmental knowledge on the environmental behavior of people 2016 (Zareie \& Navimipour, 2016).

Environmental awareness and Environmental Kuznets curve (Chen, Huang, \& Lin, 2019). 2019 


\section{Results and Discussion}

In general, environmental awareness is very important for a comfortable life sake. To find out how the level of public awareness, this study has categorized aspects of environment needs. In shaping awareness, there are some stages needed such as knowledge, attitudes and behaviors (Ham, Mrčela, \& Horvat, 2016). Attitudes are divided into two, namely pro-environment and not proenvironment (M. Wiernik, S. Ones, \& Dilchert, 2013). Pro-environment group strongly avoids the environmental damage, the raw materials use that are not excessive and not exploit the natural resources on a large scale. The pro-environment tends to carry out activities according to their personal desires and benefits without regarding the environmental conditions.

Research findings from several articles are grouped into related aspects. Table 4 shows the aspects that must be present in making environmental awareness measurement instruments.

Table 4. Aspects of environmental awareness measuring instruments

\begin{tabular}{|c|c|c|c|c|}
\hline \multirow{2}{*}{ No } & \multirow{2}{*}{$\begin{array}{l}\text { Researched } \\
\text { Aspects }\end{array}$} & \multicolumn{3}{|l|}{ Indicator } \\
\hline & & Knowledge & Attitude & Behavior \\
\hline \multirow[t]{4}{*}{1} & \multirow[t]{4}{*}{ Pro-environment } & $\begin{array}{l}\text { Know the } \\
\text { classification }\end{array}$ & $\begin{array}{l}\text { Remind not } \\
\text { to litter }\end{array}$ & $\begin{array}{l}\text { Trash disposing by } \\
\text { sorting according to its } \\
\text { classification }\end{array}$ \\
\hline & & $\begin{array}{l}\text { Knowing things that } \\
\text { can pollute the } \\
\text { environment }\end{array}$ & $\begin{array}{l}\text { Remind to always } \\
\text { protect } \\
\text { environment } \text { the } \\
\text { pollution }\end{array}$ & $\begin{array}{l}\text { Implement the rules of } \\
\text { the government not to } \\
\text { pollute the } \\
\text { environment }\end{array}$ \\
\hline & & $\begin{array}{l}\text { Know the types of } \\
\text { animals that are } \\
\text { protected }\end{array}$ & $\begin{array}{l}\text { Remind not to } \\
\text { capture or even kill } \\
\text { protected animals }\end{array}$ & $\begin{array}{l}\text { Helping } \\
\text { supporting }\end{array}$ \\
\hline & & $\begin{array}{l}\text { Know about the } \\
\text { greening function }\end{array}$ & $\begin{array}{l}\text { Remind to always } \\
\text { re-plant after } \\
\text { cutting down trees }\end{array}$ & $\begin{array}{l}\text { Do not cut trees } \\
\text { carelessly }\end{array}$ \\
\hline \multirow[t]{4}{*}{2} & \multirow[t]{4}{*}{$\begin{array}{l}\text { Not } \\
\text { pro-environment }\end{array}$} & $\begin{array}{l}\text { Know the } \\
\text { classification of waste }\end{array}$ & $\begin{array}{l}\text { Not reminding not } \\
\text { to litter }\end{array}$ & Littering \\
\hline & & $\begin{array}{l}\text { Knowing things that } \\
\text { can pollute the } \\
\text { environment }\end{array}$ & $\begin{array}{l}\text { Do not remind to } \\
\text { always protect the } \\
\text { environment from } \\
\text { pollution }\end{array}$ & $\begin{array}{l}\text { Do things that can } \\
\text { pollute the } \\
\text { environment }\end{array}$ \\
\hline & & $\begin{array}{l}\text { Know the types of } \\
\text { animals that are } \\
\text { protected }\end{array}$ & $\begin{array}{l}\text { Not reminding not } \\
\text { to capture or even } \\
\text { kill protected } \\
\text { animals }\end{array}$ & $\begin{array}{l}\text { Hunt animals as you } \\
\text { wish }\end{array}$ \\
\hline & & $\begin{array}{l}\text { Know about the } \\
\text { greening function }\end{array}$ & $\begin{array}{l}\text { Do not remind to } \\
\text { always re-plant } \\
\text { after cutting down } \\
\text { trees }\end{array}$ & $\begin{array}{l}\text { Cutting trees } \\
\text { carelessly }\end{array}$ \\
\hline
\end{tabular}


Positive aspects for pro-environment are intended to see the level of concern for the environment that is friendly and comfortable. Meanwhile, pro-environment sees the level of ignorance of participants towards environmental sustainability. The research indicators are intended to direct the training process and the results of public awareness of the environment in accordance with the initial objectives of environmental awareness training.

Knowledge about caring for the environment must be followed by a caring attitude and always reminding the environment and ending with behaviors or actions that protect the environment and not damage the environment. These three indicators fulfilled means that community awareness of the environment has increased. If one indicator is not fulfilled, then environmental awareness is still considered to be lacking because the three indicators must complement and support each other.

Some researchers use the Likert scale in the process of environmental awareness research, the research instrument is made with the three indicators of knowledge, attitudes and behavior in a single unit. These three indicators are related because environmental awareness will emerge when they already have knowledge about the importance of the environment. While knowledge about the environment will not be useful if it is not accompanied by attitudes and behaviors that reflect environmental care. Usually people only know that it is not allowed to litter, but when the trash can is far enough, tend will tend to do it (litter).

Building environmental awareness needs to be done at an early age, because awareness and care for the environment is built from various stages to become a habit and to become a culture. An environmentally conscious culture can be applied from an early age because when it grows up it will be difficult to change habits that are not environmentally friendly and are already entrenched. An environmentally conscious culture can be started from kindergarten, elementary school and junior high school. For adult communities who still do not have the three indicators, it is necessary to conduct training or environmental seminars on a regular and ongoing basis accompanied by direct practice of caring for the environment.

\section{Conclusion}

This study literature is helping in recommending a list of aspects and indicators in the measurement of environmental awareness. The aspects taken from several research results that have been verified by experts. The implications of this research will help academics in recommending a set of key instruments for measuring environmental awareness. In the future, academics need to prioritize environmental awareness content to connect the gap between proenvironment parties and those that are not pro-environment, so that it can be a solution in minimizing environmental damage.

The aspects that must have in the measurement of environmental awareness is a question or a positive and negative statement. This is to ensure the truth and honesty in filling out the questionnaire after carrying out workshops or environmental awareness training. The three 
indicators namely knowledge are the things learned, attitudes are the thought habit and behavior that is actions that arise based on knowledge and attitudes. This is intended to familiarize and civilize the environment awareness with the three spheres of knowledge insights, habituation of attitudes and culture-conscious behavior that is entrenched. The three indicators are a unified whole to develop the environmental awareness community. This literature review can be used as a reference for further research in making research instruments on environmental awareness training for the surrounding community.

\section{References}

Albertini, E. (2013). Does environmental management improve financial performance? A metaanalytical review. Organization \& Environment, 26(4), 431-457.

Anbalagan, G., and Srivastava, R. (2016). Developing Environmental Awareness through Open and Distance Learning System. Pakistan Journal of Distance and Online Learning, 1(1), 49-57.

Arlt, D., Hoppe, I., and Wolling, J. (2011). Climate change and media usage: Effects on problem awareness and behavioral intentions. International Communication Gazette, 73(1-2), 4563.

Ballantyne, R., Packer, J., and Falk, J. (2011). Visitors' learning for environmental sustainability: Testing short-and longterm impacts of wildlife tourism experiences using structural equation modeling. Tourism Management, 32(6), 12431252.

Belinda, Y. (2017). The Influence of Public Awareness of the Environment on the Community's Interest in Saving at the Sawo Kecik Garbage Bank Housing the Gebang Permai Temple in Yogyakarta. Thesis: Sanata Dharma University.

Cetin, G., and Nisanci, S. H. (2010). Enhancing Students' Environmental Awareness. ProcediaSocial and Behavioral Sciences, 2(2), 1830-1834.

Chen, X., Huang, B., and Lin, C. T. (2019). Environmental awareness and environmental Kuznets curve. Economic Modelling, 77, 2-11.

Culiberg, B., \& Rojšek, I. (2008). Understanding environmental consciousness: a multidimensional perspective. Grbac: poglavlje u knjizi.

Douglas, A. C., Mills, J. E., Niang, M., Stepchenkova, S., Byun, S., Ruffini, C., ... and Blanton, M. (2008). Internet addiction: Meta-synthesis of qualitative research for the decade 19962006. Computers in human behavior, 24(6), 3027-3044.

Flammer, C. (2013). Corporate Social Responsibility and Shareholder Reaction: The Environmental Awareness of Investors. Academy of Management Journal, 56(3), 758-781.

Ham, M., Mrčela, D., and Horvat, M. (2016). Insights for Measuring Environmental Awareness. Ekonomski Vjesnik: Review of Contemporary Entrepreneurship, Business, and Economic Issues, 29(1), 159-176.

Hartmann, P., and Apaolaza-Ibáñez, V. (2012). Consumer Attitude and Purchase Intention toward Green Energy Brands: The Roles of Psychological Benefits and Environmental Concern. Journal of Business Research, 65(9), 1254-1263. 
Haslinda, A., and Fuong, C. C. (2010). The implementation of ISO 14001 environmental management system in manufacturing firms in Malaysia. Asian Social Science, 6(3), 100.

Hiramatsu, A., Kurisu, K., and Hanaki, K. (2016). Environmental Awareness in Daily Activities Measured by Negative Prompts. Sustainability, 8(1), 24.

Hsieh, H. F., and Shannon, S. E. (2005). Three approaches to qualitative content analysis. Qualitative health research, 15(9), 1277-1288.

Husna, A. H., Ramadhani, E. A., Eva, D. T., Yulita, A. F., and Suhartono, E. (2014). The role formation of methylglyoxal, carbonyl compound, hydrogen peroxide and advance oxidation protein product induced cadmium in ovarian rat. Int J Chem Eng Appl, 5(4), 319-23.

Kubiszewski, I., Costanza, R., Franco, C., Lawn, P., Talberth, J., Jackson, T., and Aylmer, C. (2013). Beyond GDP: Measuring and achieving global genuine progress. Ecological Economics, 93, 57-68.

Kurniawati, A., Hardjanto, U. S., and Herawati, R. (2013). Air Quality Control in the City of Semarang. Diponegoro Law Journal, 2(3), 1-11.

Lafuente, R., and Sánchez, M. J. (2010). Defining and Measuring Environmental Consciousness. Revista International de Sociologia (RIS), 68(3), 731-55.

Lee, K. H., and Shin, D. (2010). Consumers' responses to CSR activities: The Linkage between Increased Awareness and Purchase Intention. Public Relations Review, 36(2), 193-195.

M. Wiernik, B., S. Ones, D., and Dilchert, S. (2013). Age and Environmental Sustainability: A MetaAnalysis. Journal of Managerial Psychology, 28(7/8), 826-856.

Murzi, H., Mazzurco, A., Pikaar, I., and Gibbes, B. (2019). Measuring development of environmental awareness and moral reasoning: A case-study of a civil engineering course. European Journal of Engineering Education, 1-15.

Nor, N. M., Bahari, N. A. S., Adnan, N. A., Kamal, S. M. Q. A. S., and Ali, I. M. (2016). The effects of environmental disclosure on financial performance in Malaysia. Procedia Economics and Finance, 35, 117-126.

Noviyanti, T., and Diharto, A. K. (2018). The Effect of Skepticsm and Environmental Concern on Green Purchase Behavior with Perceived Consumer Effectiveness as Variables of Mediation. Doctoral Dissertation, Institut Agama Islam Negeri Surakarta.

Peña-Fernández, A., González-Muñoz, M. J., and de los Ángeles Peña, M. (2015). Designing training for teaching environmental toxicology to specialized pharmacists. Currents in Pharmacy Teaching and Learning, 7(6), 864-868.

Perkins, H. E. (2010). Measuring Love and Care for Nature. Journal of Environmental Psychology, $30(4), 455-463$.

Phan, T. N., and Baird, K. (2015). The Comprehensiveness of Environmental Management Systems: The Influence of Institutional Pressures and the Impact on Environmental Performance. Journal of Environmental Management, 160, 45-56.

Salim, E. (1982). Conservation and development. Environmentalist, 2(2), 109-116.

Sudarman, S., Saputra, D. D., Karnowo, K., and Febrian, F. (2019). Minimization Of Air Pollution Through Sustainable Development of Eco-Industrial Parks in China Effects of Managers' 
Environmental Awareness on The Relationship Between Practice and Performance. Rekayasa: Jurnal Penerapan Teknologi dan Pembelajaran, 16(2), 165-172.

Waskito, J., and Harsono, M. (2012). Green Consumer: Description of the Joglosemar Community's Level of Awareness and Concern for Environmental Sustainability. Journal of Management Dynamics, 3 (1).

Wells, V. K., Manika, D., Gregory-Smith, D., Taheri, B., and Mc Cowlen, C. (2015). Heritage Tourism, CSR and the Role Employee Environmental Behavior. Tourism Management, 48, 399-413.

Zareie, B., and Navimipour, N. J. (2016). The impact of electronic environmental knowledge on the environmental behavior of people. Computers in Human Behavior, 59, 1-8. 